\title{
Features of Roof Rainwater Runoff Pollution in a Northern Coastal City under the Effects of Multiple Factors
}

\author{
Lingling Zhang ${ }^{1}$, Wenping $\mathrm{Liu}^{2}$, Bin Zheng ${ }^{1 *}$, Ao Xu${ }^{3}$, Baode $\mathrm{Sun}^{3}$ \\ ${ }^{1}$ School of Architecture, Yantai University, Yantai 264005, China \\ ${ }^{2}$ Yantai Architectural Design and Research Co., Ltd, Yantai 264005, China \\ ${ }^{3}$ School of Civil Engineering, Yantai University, Yantai 264005, China
}

Corresponding Author Email: zb_jzxy@ytu.edu.cn

https://doi.org/10.18280/ijsdp.150403

Received: 21 January 2020

Accepted: 7 March 2020

\section{Keywords:}

runoff pollution, air pollution, season, rainfall intensity, antecedent dry period, outflow law

\begin{abstract}
This paper attempts to disclose the features of roof rainwater runoff pollution under the effects of air pollution, season, rainfall intensity, and antecedent dry period. Targeting an inclined tile roof in Yantai, China, this paper samples rainwater multiple times from March to November, 2018. The quality of roof rainwater samples in 12 representative natural rainfalls was monitored, and the curves of the main pollutants in these samples were plotted. On this basis, the authors analyzed the change features and outflow laws of the main pollution indices of roof runoff rainwater under the effects of different factors. The results show that: The degree of air pollution directly bears on rainwater quality. The rainfall also has a certain impact on air pollution indices. Season is the leading influencing factor of the quality of roof runoff rainwater. The best rainwater quality was observed in autumn, followed by that in spring and then that in summer. In the first 10-20min of each rainfall, the pollutant contents decreased at a growing rate with the increase of rainfall intensity. The increments of the initial pollutant contents reached the maximum at the antecedent dry period of $10 \mathrm{~d}$. The changes of all pollution indices of roof runoff rainwater could be divided into the sudden change phase, the transition phase, and the stable phase. Roof rainwater runoff has an obvious initial washing effect, and exerts a secondary washing effect. The research results provide a good reference for northern coastal cities to rationalize the parameters of rainwater purification facilities.
\end{abstract}

\section{INTRODUCTION}

Rainwater is a water resource that can be accessed at a low cost. Many countries have attached great importance to rainwater, due to its importance in conserving water sources, maintaining water and soil, and protecting the ecoenvironment [1-3]. For better use of rainwater resource, China has recently released a series of national and local polices and measures to promote the collection and utilization of rainwater. For example, The Promotion Measures for Green Buildings in Shandong Province, which was issued on March 1, 2019, stipulate that the newly built civil buildings, whose construction area surpasses $20,000 \mathrm{~m}^{2}$, must have a rainwater collection and utilization system that meets national and provincial standards. The Measures also require newly built civil buildings to prioritize the use of rainwater and other nonconventional water sources for landscape, greening, and road washing [4].

Much results have been achieved on the features of roof rainwater runoff pollution [5-7]. Some explored how different roofing materials affect the features of rainwater runoff pollution [8-10], while some studied the impact of various environmental factors on runoff rainwater quality [11-13]. The most significant environmental impact is the spatiotemporal migration of pollutants in rainwater during social activities [14-16], especially that of air pollutants [17-19]. However, there are clear regional differences in the features of roof rainwater runoff pollution [20-22]. The rainwater runoff pollution of a region should be characterized accurately in the light of regional conditions, rather than generalized from the features in other regions [23]. Moreover, scholars have emphasized the roof rainwater runoff pollution in inland regions [24-26] over that in northern coastal cities like Yantai.

To characterize the roof rainwater runoff pollution in northern coastal cities, it is necessary to collect representative local samples of natural rainfall and roof rainwater. This paper briefly analyzes the necessity and feasibility of rainwater utilization in Yantai, and select the inclined tile roof, the typical roof in that city, as the object. Following control variates method, the features of roof rainwater runoff pollution in Yantai were examined under the effects of air pollution, season, rainfall intensity, and antecedent dry period. Besides, the outflow laws of roof runoff rainwater were summarized from the variation curves of pollutants. The research results provide a good reference for northern coastal cities to utilize rainwater, and enrich the evidence for urban non-point source pollution, laying the basis for the design of reasonable rainwater purification facilities.

\section{RAINFALL SITUATION IN YANTAI}

Located in the northeast of the Shandong Peninsula, Yantai is a coastal city bordering the Bohai Sea and the Yellow Sea. 
The annual mean rainfalls of Yantai in 2009-2019 were collected from Yantai Meteorological Bureau, and prepared into a bar chart (Figure 1). Obviously, the annual mean rainfalls of Yantai were evenly distributed in the past ten years, exhibiting a declining trend after 2013. Despite the relatively abundant rainfall, Yantai is in lack of water resources: the percapital amount of water resources is less than $1 / 5$ of the national level [27]. Facing the tight water supply, it is imperative to develop and utilize the rainwater resource in a reasonable fashion.

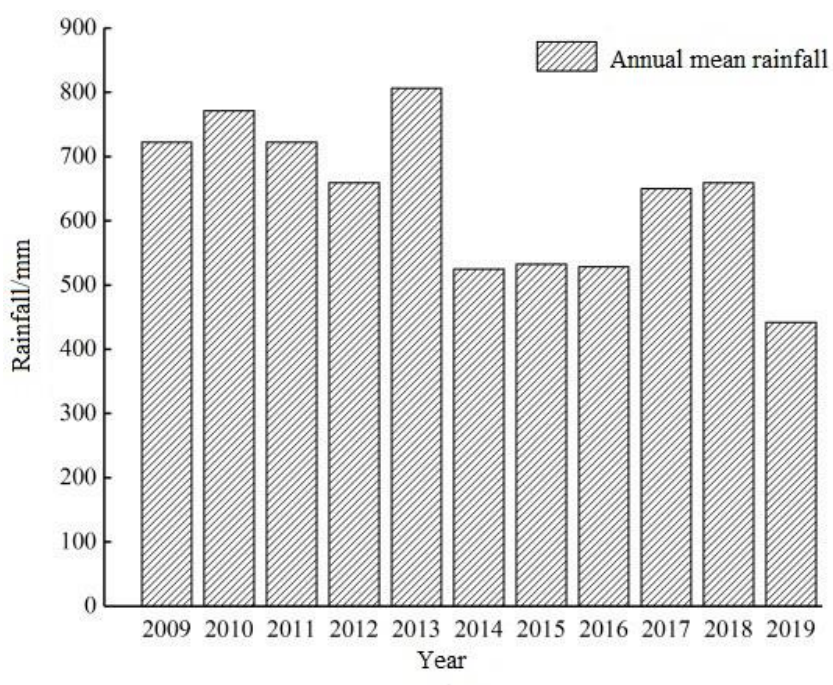

Figure 1. Annual mean rainfalls in Yantai

\section{INFLUENCING FACTORS OF ROOF RAINWATER QUALITY}

Roof rainwater runoff pollution is mainly measured by the common indices of water quality, namely, chemical oxygen demand (COD), suspended solids (SS), ammonia nitrogen $\left(\mathrm{NH}_{4}-\mathrm{N}\right)$, turbidity, total nitrogen $(\mathrm{TN})$, and hydrogen ion concentration $(\mathrm{pH})$.

Roof rainwater quality could be affected by various factors, such as roof properties (roof material, age, slope, etc.), environmental features (air pollution, geographic location, season, etc.), and rainfall features (rainfall intensity, antecedent dry period, rainfall duration, etc.)

This paper mainly investigates how rainwater quality is influenced by air pollution, season, rainfall intensity, and antecedent dry period.

(1) The air pollution reflects the impact of local air pollution on the quality of natural rainwater. During the rain, the rainwater washes the air before falling onto the roof, forming a runoff. The pollutants in roof rainwater are partly entrained in natural rainfall.

(2) The season reflects the impact of air temperature and seasonal light intensity on roof rainwater pollution. The quality of roof rainwater depends heavily on sunshine and other high-temperature conditions. The roof rainwater is of poor quality in summer, owing to the lasting sunshine.

(3) The rainfall intensity reflects the impact of the rainfall per unit time on roof rainwater quality. In general, the greater the rainfall intensity, the lighter the pollution load of the sample.

(4) The antecedent dry period reflects the impact of the previous rainfall frequency, i.e. the interval between the current and the previous rainfalls, on roof rainwater quality. Normally, the longer the interval, the more polluted the rainwater on the same roof.

\section{SAMPLING PRINCIPLES}

The sampling site is a typical multi-story building in Zhifu District, Yantai. The roof of the building is the inclined tile roof, which is common in the region. The sampling was carried out during 12 rainfalls in 2018, respectively on April 14, April 22, May 2, June 13, June 25, July 9, July 10, August 13, August 19, September 20, October 8, and November 7. On each of these dates, effective roof runoff was formed, under the combined effects of rainfall intensity, season (spring, summer, and autumn), and antecedent dry period. Each sampling began after runoff was formed by roof rainwater. The samples were collected with a $50 \mathrm{~mL}$ plastic bottle at an interval of $2-10 \mathrm{~min}$, depending on the rainfall and turbidity. The values of influencing factors of the collected samples are listed in Table 1.

Table 1. The values of influencing factors for the collected samples

\begin{tabular}{ccccc}
\hline Date & $\begin{array}{c}\text { Rainfall } \\
(\mathbf{m m})\end{array}$ & $\begin{array}{c}\text { Mean rainfall } \\
\text { intensity } \mathbf{( m m} / \mathbf{h})\end{array}$ & $\begin{array}{c}\text { Antecedent dry period } \\
(\mathbf{d})\end{array}$ & $\begin{array}{c}\text { Number of } \\
\text { samples (each) }\end{array}$ \\
\hline April 14 & 6 & 4 & 9 & 11 \\
April 22 & 42.3 & 25 & 7 & 9 \\
May 2 & 16 & 10 & 8 & 10 \\
June 13 & 34.6 & 18 & 21 & 13 \\
June 25 & 54.4 & 20 & 1 & 15 \\
July 9 & 58 & 21 & 10 & 12 \\
July 10 & 35.9 & 20 & 0 & 11 \\
August 13 & 37.1 & 17 & 16 & 10 \\
August 19 & 44.5 & 23 & 9 & 10 \\
September 20 & 21.5 & 21 & 7 & 11 \\
October 8 & 9.4 & 5 & 6 & 9 \\
November 7 & 8.5 & 7 & 7 & 8 \\
\hline
\end{tabular}




\section{RESULTS ANALYSIS}

\subsection{Air pollution}

Air pollution, which depends on the geographical location, is the main cause of natural rainfall pollution. The degree of natural rainfall pollution greatly affects the quality of roof rainwater. The monthly air pollution indices of Yantai in 2018 and the quality of the 12 natural rainfalls are sorted out as in Figures 2 and 3, respectively.

As shown in Figures 2 and 3, the water quality indices of natural rainfalls changed in the same trend as the degree of air pollution: climbing up to the peak in spring, falling to the valley in summer, and rising month by month in autumn. Thus, the degree of air pollution directly bears on rainwater quality.

According to the relationship between monthly cumulative rainfalls and air pollutant contents (Figure 2), the rainfall has a certain impact on air pollution indices; the greater the

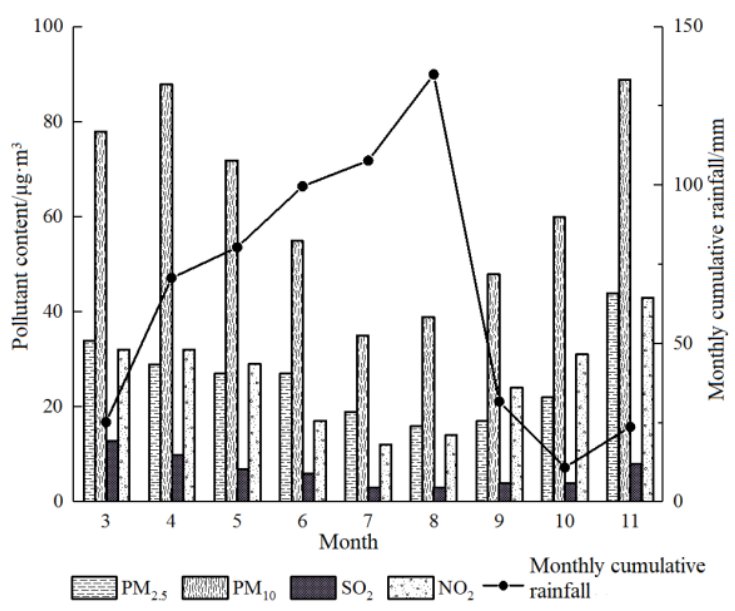

Figure 2. Monthly air quality in Yantai monthly rainfall, the lower the air pollutant contents, and the better the air quality.

Then, the control variates method was employed to further disclose the impact of air pollution on the pollution indices of natural rainfall in different seasons. Similar in rainfall intensity and antecedent dry period, three natural rainfalls occurring on April 22, July 9, and September 20 were selected from spring, summer, and autumn, respectively. The mean pollutant contents of the three natural rainfalls are compared in Table 2.

The comparison shows that the main pollution indices like $\mathrm{COD}, \mathrm{TP}$, and $\mathrm{pH}$ of the three natural rainfalls were close to the thresholds for level III water quality, as specified in Environmental Quality Standards for Surface Water (GB3838-2002). Hence, the natural rainwater is lightly polluted and basically safe. However, the TN and SS of the three natural rainfalls seriously surpassed the limits, indicating that the TN and SS of natural rainwater are greatly affected by air pollution.

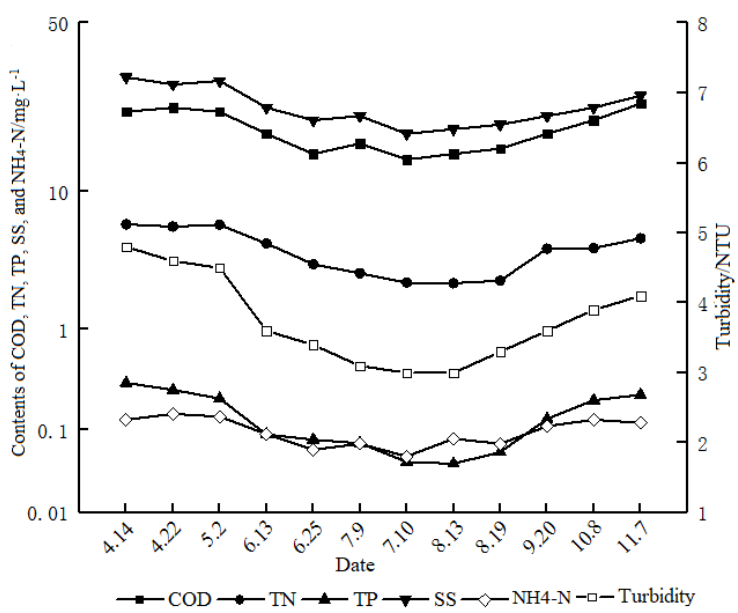

Figure 3. Curve of mean pollutant contents in natural rainfall

Table 2. Mean pollutant contents of three natural rainfalls

\begin{tabular}{ccccccccc}
\hline Date & COD (mg/L) & Color & Turbidity (NTU) & TN (mg/L) & TP (mg/L) & SS (mg/L) & NH4-N (mg/L) & pH \\
\hline April 22 & 24 & $<4$ & $<3$ & 6.11 & 0.267 & 32 & 0.15 & 6.4 \\
July 9 & 18 & $<4$ & $<3$ & 3.87 & 0.071 & 22 & 0.07 & 6.6 \\
September 20 & 20 & $<4$ & $<3$ & 4.32 & 0.132 & 25 & 0.11 & 6.7 \\
A & $20-30$ & 30 & 10 & - & - & $5-10$ & $10-20$ & $6.5-$ \\
B & 20 & - & - & 1 & 0.2 & - & 9 & $6-9$ \\
\hline
\end{tabular}

Note: A stands for Technical Code for Rainwater Management and Utilization of Building and Sub-District (GB50400-2016); B stands for level III in Environmental Quality Standards for Surface Water (GB3838-2002).

\subsection{Effect of influencing factors of roof rainwater runoff pollution}

From the start of rainfall to the formation of roof runoff, pollutants are gathered as the rainwater washes the air and the roof. The mean pollutant contents of the roof runoff rainwater were monitored in each of the 12 rainfalls. Part of the monitoring results are presented in Figure 4.

Comparing Figures 3 and 4, the COD and SS of roof runoff rainwater were found to be much higher than those of natural rainfall, indicating that roof rainwater runoff is polluted more seriously than natural rainfall. This means the pollutants of roof rainwater runoff mainly come from roof pollutants, rather than pollutants in the air. The roof is the major pollution source of the samples collected in the early phase.

Figure 4 also shows the relationship between different factors and the quality of roof runoff rainwater. It can be found that the quality of roof runoff rainwater was always affected by season, rainfall intensity, and antecedent dry period. Overall, the best rainwater quality was observed in autumn, followed by that in spring and then that in summer. Therefore, season has a greater impact on the quality of roof runoff rainwater than the other two factors.

For the rainfalls in each season, the mean pollutant contents are negatively correlated with rainfall intensity. For the rainfalls in all three seasons, the COD and SS contents followed the same trend as the antecedent dry period, revealing the good correlation between these contents and this influencing factor. By the control variates method, the natural rainfalls with similar rainfall intensities and antecedent dry periods were selected to further analyze the change laws of roof rainwater pollution under the effects of different factors. 


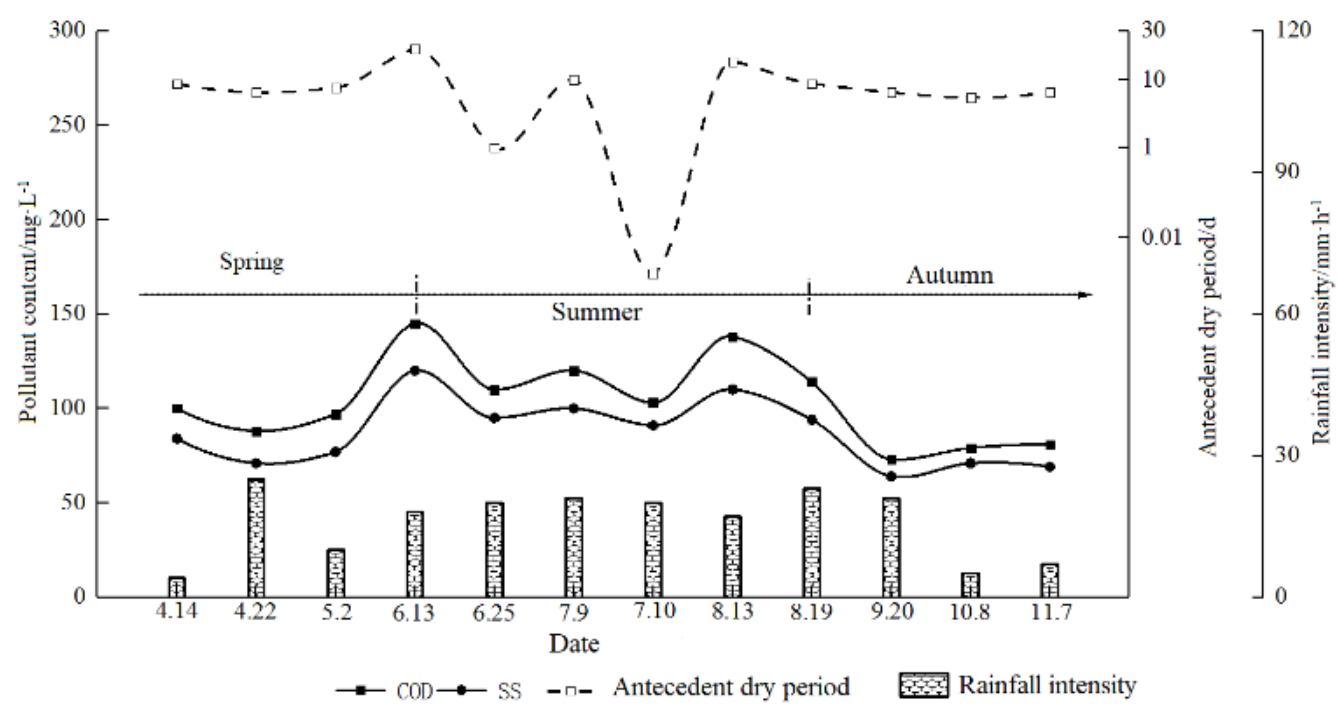

Figure 4. The mean pollutant contents of roof runoff rainwater in 12 rainfalls

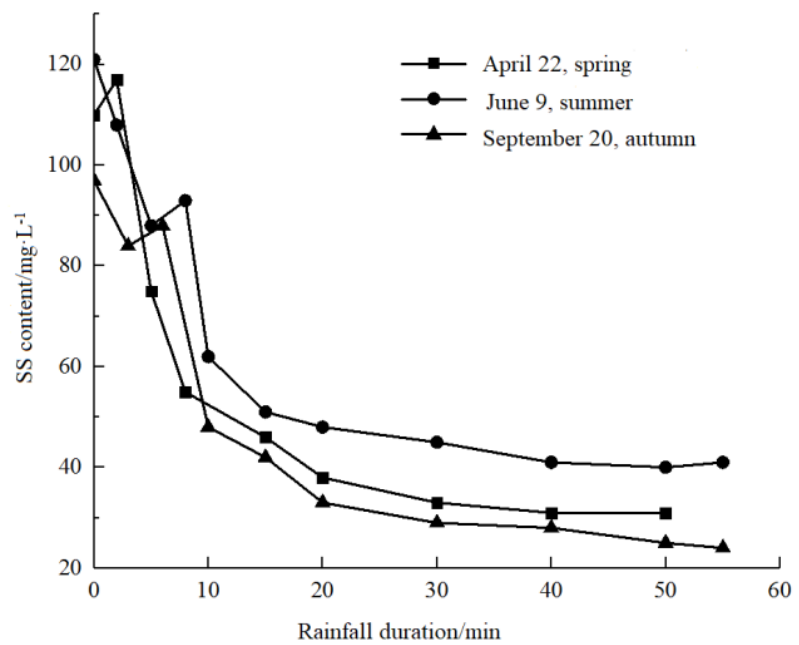

(a) COD variation

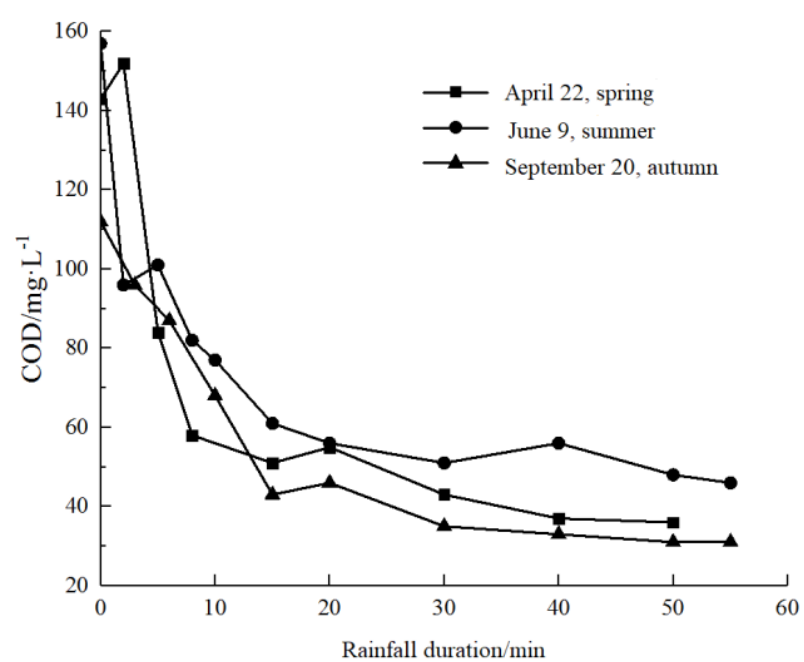

(b) SS variation

Figure 5. Changes of COD and SS in roof runoff rainwater with rainfall duration in different seasons

\subsubsection{Season}

Different seasons vary in temperature and light intensity, which may affect the quality of roof runoff rainwater. Similar in rainfall intensity and antecedent dry period, three natural rainfalls occurring on April 22, July 9, and September 20 were selected as the typical rainfall of spring, summer, and autumn, respectively. The quality of roof runoff water in each rainfall was measured, and used to plot the curves of runoff pollutants (Figure 5).

As shown in Figure 5, the initial pollutant contents of roof runoff rainwater changed greatly from season to season. In summer, the initial pollutant contents were maximized. The initial contents of COD and SS were $157 \mathrm{mg} / \mathrm{L}$ and $121 \mathrm{mg} / \mathrm{L}$, respectively. The main reasons include the high temperature and light intensity in summer. The organic pollutants within the roof are easily decomposed at high temperature, while the water quality is prone to degradation under intense light. In spring, the contents of COD and SS were $143 \mathrm{mg} / \mathrm{L}$ and 110 $\mathrm{mg} / \mathrm{L}$, respectively, higher than those in autumn. This is the result of the lack of rainfall in winter and spring. After longterm accumulation, the roof pollutants could not be washed away. The largest differences between the three rainfalls in initial contents of COD and SS were $40 \mathrm{mg} / \mathrm{L}$ and $20 \mathrm{mg} / \mathrm{L}$, respectively, which are not significant.
Che et al. [25] monitored the quality of runoff rainwater on a black asphalt linoleum roof in Beijing. The monitoring results show that the roof runoff rainwater contained lots of pollutants in spring and summer. For example, the COD in spring and summer was about $1,500 \mathrm{mg} / \mathrm{L}$ higher than that in autumn. The huge difference arises from the roofing material. The linoleum roof releases a huge amount of pollutants at high temperature $[28,29]$. The roof in our research is made of tiles, which differs greatly from the linoleum.

In all three seasons, the COD and SS contents both decreased with the growing rainfall duration, and eventually stabilized. After stabilization, the three seasons can be ranked as summer $>$ spring $>$ autumn in descending order of pollutant contents.

\subsubsection{Rainfall intensity}

Both rainfall intensity and rainfall have multiple effects on roof pollutants, such as washing, dilution, and dissolution. Hence, the quality variation of roof runoff rainwater water with rainfall duration is largely determined by rainfall intensity and rainfall. Similar in antecedent dry period, three spring rainfalls occurring on April 14, April 22, and May 2 were selected for water quality measurement. Figure 6 shows the pollutant contents of roof runoff rainwater in each rainfall 
at different rainfall intensities. Figure 7 displays the variation of COD and SS of roof runoff rainwater with rainfall duration in all three rainfalls at different rainfall intensities.

As shown in Figure 6, the pollutant contents in roof runoff rainwater are not positively correlated with rainfall intensity. In the first $10-20 \mathrm{~min}$ of each rainfall, the pollutant contents decreased at a growing rate with the increase of rainfall intensity. After 20-30min, the pollutant contents decreased at a reducing rate until stabilization, despite the increase of rainfall intensity.

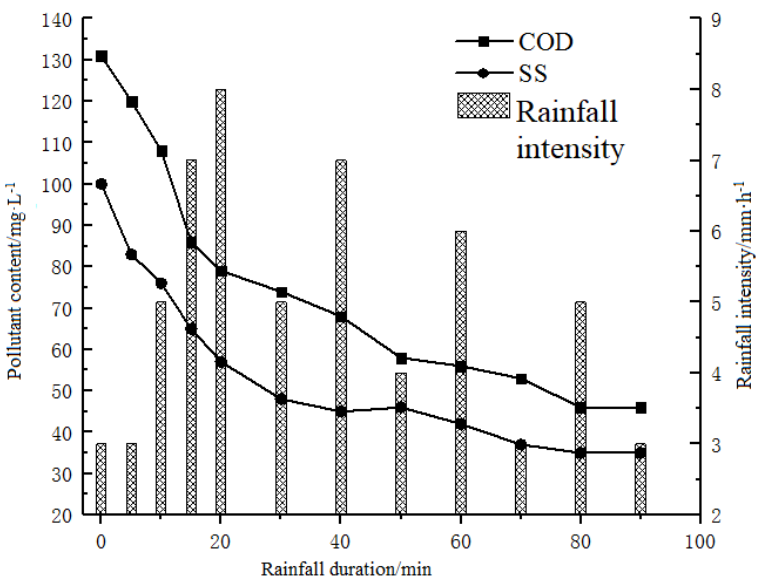

(a) April 14

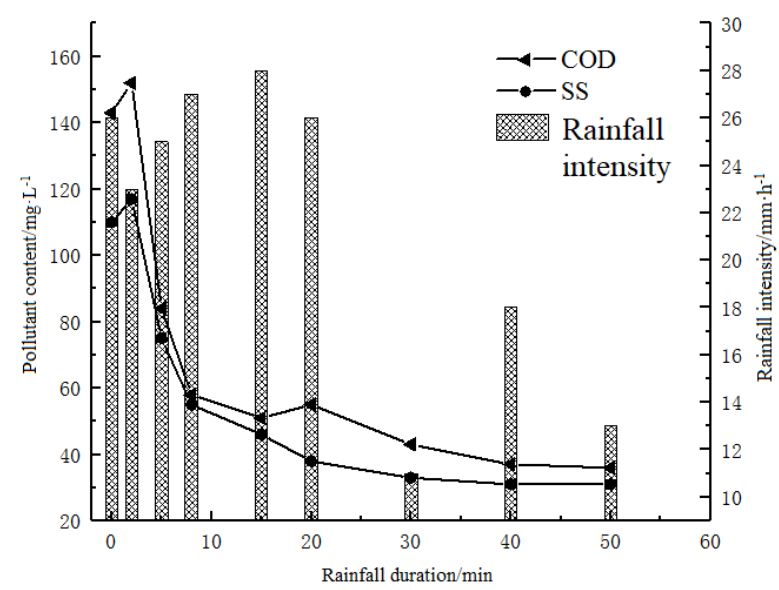

(b) April 22

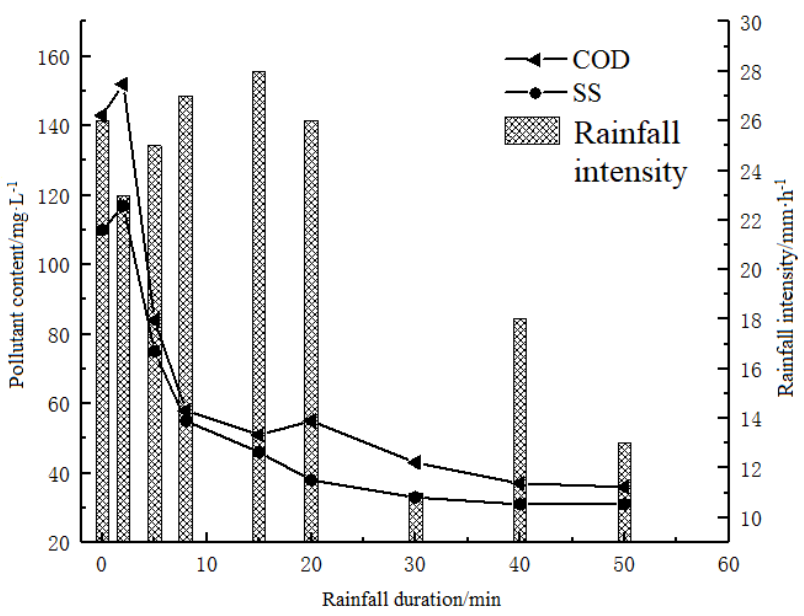

(c) May 2

Figure 6. The pollutant contents of roof runoff rainwater in each rainfall at different rainfall intensities

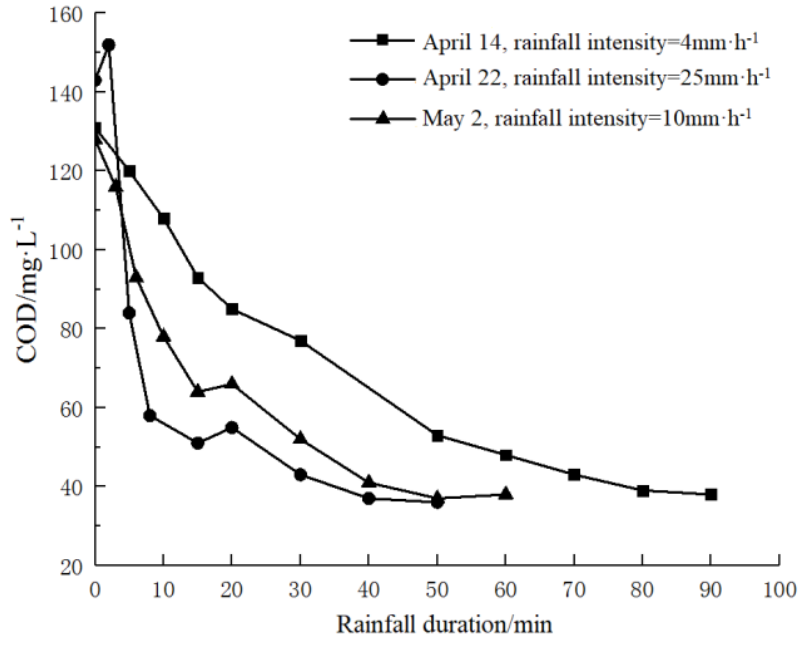

(a) COD variation

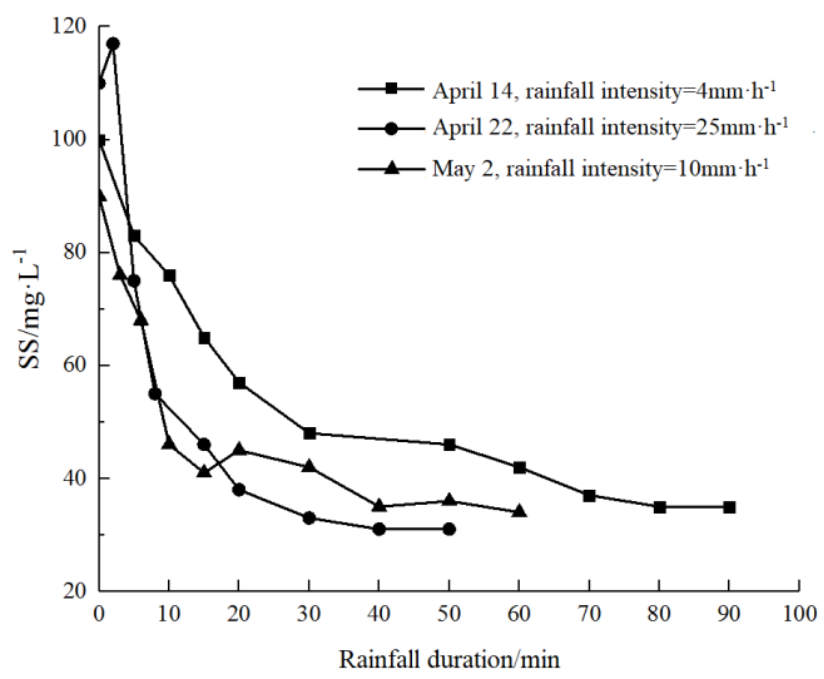

(b) SS variation

Figure 7. The variation of COD and SS of roof runoff rainwater with rainfall duration in all three rainfalls at different rainfall intensities

As shown in Figure 7, the contents of COD and SS in all three rainfalls exhibited a downward trend with the growth of rainfall duration, and eventually stabilized. The best quality of roof runoff water was observed on April 22. Besides, the pollutant indices decreased faster and deeper under the initial runoff on April 22 than on the other two dates. Take the COD variation on April 22 for example. Within 15min, the COD contents dropped by $92 \mathrm{mg} / \mathrm{L}$ at $6.1 \mathrm{mg} / \mathrm{min}$ from $143 \mathrm{mg} / \mathrm{L}$ to $51 \mathrm{mg} / \mathrm{L}$

Table 3 lists the decrements and decreasing rates of COD contents within $15 \mathrm{~min}$ at different rainfall intensities. It can be learned that, with the growth in rainfall intensity, the rainwater washed the roof more effectively, and the roof pollutants were diluted faster and faster. Therefore, the more intense the rainfall, the faster and the deeper the decline of pollutant content, and the better the quality of roof runoff rainwater.

\subsubsection{Antecedent dry period}

On sunny days, pollutants will accumulate on the roof. The contents of the accumulated pollutants directly bear on the quality of roof rainwater runoff. Hence, the antecedent dry period was used to characterize the degree of accumulation of roof pollutants, laying the basis for the prediction of roof runoff water quality [30]. 
Table 3. COD variations within $15 \mathrm{~min}$

\begin{tabular}{ccccc}
\hline Date & Initial content (mg/L) & 15min content $(\mathbf{m g} / \mathbf{L})$ & Decrement $(\mathbf{m g} / \mathbf{L})$ & Decreasing $\mathbf{~ r a t e ~}(\mathbf{m g} / \mathbf{m i n})$ \\
\hline April 14 & 131 & 93 & 38 & 2.5 \\
April 22 & 143 & 51 & 92 & 6.1 \\
May 2 & 128 & 64 & 64 & 4.3 \\
\hline
\end{tabular}

To reveal the relationship between antecedent dry period and initial pollutant contents, six rainfalls with similar rainfall intensities were selected from the same season: June 13, June 25, July 9, July 10, August 13, and August 19. As shown in Figure 8, the initial COD and SS contents in roof runoff rainwater increased with the antecedent dry period, but differed in increment. Once the antecedent dry period exceeded 10d, the initial COD and SS contents both increased at much slower rates. Thus, the antecedent dry period has a great impact on the initial pollutant contents in roof rainwater runoff. The longer the antecedent dry period, the higher the initial pollutant contents in roof rainwater runoff. However, the increments of the initial pollutant contents reached the maximum at the antecedent dry period of $10 \mathrm{~d}$.

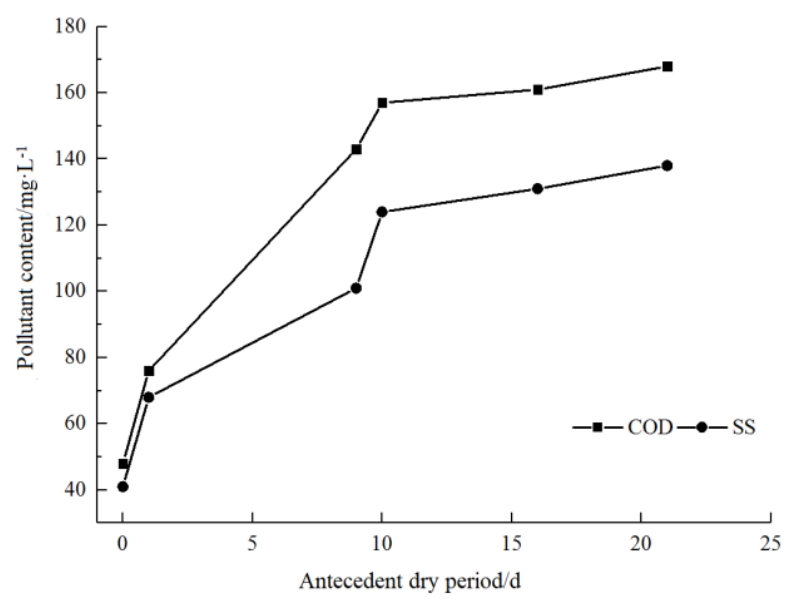

Figure 8. The relationship between initial pollutant contents and antecedent dry period

\subsection{Outflow laws of roof runoff rainwater}

The changes of roof rainwater runoff pollution show different features under the effect of different factors. However, there are general outflow laws of the roof runoff rainwater:

(1) The main pollution indices of roof rainwater runoff basically changed in the same trend. The changes of all indices could be divided into the sudden change phase, the transition phase, and the stable phase.

In the sudden change phase, the pollution indices fluctuated greatly, and decreased deeply at fast rates. In the transition phase, the pollution indices fluctuated slightly, and decreased moderately at slow rates. In the stable phase, the pollution indices changed very slowly, and tended to be stable. In this phase, the COD and SS contents were close to the requirements in GB3838-2002. The length of the three phases depends on multiple factors, especially rainfall intensity. The more intense the rainfall, the shorter the sudden change phase, and the earlier the dawn of the stable phase.

To reduce the workload of rainwater purification facilities and improve the efficiency of rainwater collection, the rainwater should be collected in the transition phase and the stable phase, and the parameters of the facilities should be optimized in view of the effects of rainfall intensity in different phases.

(2) During the entire runoff process, the amount of roof pollutants, which accumulated in the antecedent dry period, peaked at the start of the rainfall. Thus, the pollution indices were extremely high in the initial period of roof rainwater runoff, leading to an obvious initial washing effect. Taking the samples of June 13 for example, the initial values of COD, SS, turbidity, TN, and $\mathrm{NH}_{4}-\mathrm{N}$ were $168 \mathrm{mg} / \mathrm{L}, 138 \mathrm{mg} / \mathrm{L}, 91 \mathrm{NTU}$, $5.82 \mathrm{mg} / \mathrm{L}$, and $5.71 \mathrm{mg} / \mathrm{L}$, respectively. All of these are above the limits in the Water Quality Standards for Domestic Miscellaneous Water (GJ/T48-1999). Therefore, the initial runoff rainwater should be discarded during the collection of roof runoff rainwater.

(3) The pollutant contents of roof rainwater did not decrease linearly with the growth of rainfall duration, but rebounded in the transition phase and the stable phase. The main reason lies in the secondary washing effect, which arises from the nonuniform washing intensity or uneven distribution of roof debris. Once collected, the rainwater in the two phases should go through pollutant (e.g. COD and SS) treatment.

\section{CONCLUSIONS}

Yantai has a humid climate and abundant rainfall. The natural rainwater is slightly polluted and basically safe, and thus suitable for collection and utilization. Through the above analysis, the following conclusions were drawn:

(1) The water quality indices of natural rainfalls changed in the same trend as the degree of air pollution. The degree of air pollution directly bears on rainwater quality. The rainfall also has a certain impact on air pollution indices; the greater the monthly rainfall, the lower the air pollutant contents, and the better the air quality.

(2) Season has a greater impact on the quality of roof runoff rainwater than rainfall intensity and antecedent dry period. For the rainfalls in each season, the mean pollutant contents are negatively correlated with rainfall intensity. For the rainfalls in all three seasons, the COD and SS contents followed the same trend as the antecedent dry period, revealing the good correlation between these contents and this influencing factor. In all three seasons, the COD and SS contents both decreased with the growing rainfall duration, and eventually stabilized. After stabilization, the three seasons can be ranked as summer $>$ spring $>$ autumn in descending order of pollutant contents.

(3) In the first 10-20min of each rainfall, the pollutant contents decreased at a growing rate with the increase of rainfall intensity. After $20-30 \mathrm{~min}$, the pollutant contents decreased at a reducing rate until stabilization, despite the increase of rainfall intensity. The more intense the rainfall, the faster and the deeper the decline of pollutant content, and the better the quality of roof runoff rainwater.

(4) The longer the antecedent dry period, the higher the initial pollutant contents in roof rainwater runoff. However, the increments of the initial pollutant contents reached the 
maximum at the antecedent dry period of $10 \mathrm{~d}$, and started to shrink when the antecedent period surpassed $10 \mathrm{~d}$.

(5) The main pollution indices of roof rainwater runoff basically changed in the same trend. The changes of all indices could be divided into the sudden change phase, the transition phase, and the stable phase. The more intense the rainfall, the shorter the sudden change phase, and the earlier the dawn of the stable phase.

(6) Roof rainwater runoff has an obvious initial washing effect, and exerts a secondary washing effect, which causes the rebound of pollutant contents in the transition and stable phases.

The above conclusions provide a reference for northern coastal cities to control non-point source pollution, the second largest pollution source of urban rivers. In addition, the features of rainwater runoff pollution and general outflow laws of the typical roof in Yantai were summarized under the effects of different factors. The research results provide theoretical support to the design of efficient rainwater utilization plans and rainwater treatment techniques in northern coastal cities, and lay the basis for determining the basic parameters of rainwater purification facilities (e.g. initial discarded flow, and treatment cycle).

\section{REFERENCES}

[1] Lee, K.E., Mokhtar, M., Hanafiah, M.M., Halim, A.A., Badusah, J. (2016). Rainwater harvesting as an alternative water resource in Malaysia: Potential, policies and development. Journal of Cleaner Production, 126: 218-222. https://doi.org/10.1016/j.jclepro.2016.03.060

[2] Campisano, A., Butler, D., Ward, S., Burns, M.J., Friedler, E., DeBusk, K., Han, M. (2017). Urban rainwater harvesting systems: Research, implementation and future perspectives. Water Research, 115: 195-209. https://doi.org/10.1016/j.watres.2017.02.056

[3] Ghisi, E., Colasio, B.M., Geraldi, M., Teston, A. (2017). Rainwater harvesting in buildings in Brazil: A literature review. In Multidisciplinary Digital Publishing Institute Proceedings, 2(5): https://doi.org/10.3390/w10040471

[4] People's Government of Shandong Province. Measures for promoting Green Building of Shandong Province (Decree of the People's Government of Shandong Province No. 323) 2019-01-28.

[5] Yang, Y.Y., Toor, G.S. (2017). Sources and mechanisms of nitrate and orthophosphate transport in urban stormwater runoff from residential catchments. Water Research, $\quad 112$ : 176-184. https://doi.org/10.1016/j.watres.2018.07.011

[6] Wang, X., Tian, Y., Zhao, X. (2017). The influence of dual-substrate-layer extensive green roofs on rainwater runoff quantity and quality. Science of the Total Environment, 592: 465-476. https://doi.org/10.1016/j.scitotenv.2017.03.124

[7] Selala, M.S., Thenga, H., Jewitt, G.P.W., Chaplot, V. (2018). Comparison of the chemical quality of rainwater harvested from roof and surface run-off systems. Water SA 44(2):

223-231. https://doi.org/10.4314/wsa.v44i2.08

[8] Kuoppamäki, K., Hagner, M., Lehvävirta, S., Setälä, H. (2016). Biochar amendment in the green roof substrate affects runoff quality and quantity. Ecological
Engineering,

88

$1-9$.

https://doi.org/10.1016/j.ecoleng.2015.12.010

[9] Müller, A., Österlund, H., Nordqvist, K., Marsalek, J., Viklander, M. (2019). Building surface materials as sources of micropollutants in building runoff: A pilot study. Science of the Total Environment, 680: 190-197. https://doi.org/10.1016/j.scitotenv.2019.05.088

[10] Ouyang, W., Guo, B., Cai, G., Li, Q., Han, S., Liu, B., Liu, X. (2015). The washing effect of precipitation on particulate matter and the pollution dynamics of rainwater in downtown Beijing. Science of the Total Environment, 505: 306-314. https://doi.org/10.1016/j.atmosenv.2019.117000

[11] Keresztesi, Á., Birsan, M.V., Nita, I.A., Bodor, Z., Szép, R. (2019). Assessing the neutralisation, wet deposition and source contributions of the precipitation chemistry over Europe during 2000-2017. Environmental Sciences Europe, 31(1): 50. https://doi.org/10.1186/s12302-0190234-9

[12] Masood, S.S., Saied, S., Siddique, A., Mohiuddin, S., Hussain, M.M., Khan, M.K., Khwaja, H.A. (2018). Influence of urban-coastal activities on organic acids and major ion chemistry of wet precipitation at a metropolis in Pakistan. Arabian Journal of Geosciences, 11(24): 802 https://doi.org/10.1007/s12517-018-4118-x

[13] Deusdará, K.R.L., Forti, M.C., Borma, L.S., Menezes, R.S.C., Lima, J.R.S., Ometto, J.P.H.B. (2017). Rainwater chemistry and bulk atmospheric deposition in a tropical semiarid ecosystem: The Brazilian Caatinga. Journal of Atmospheric Chemistry, 74(1): 71-85. https://doi.org/10.1007/s10874-016-9341-9

[14] Bisht, D.S., Srivastava, A. K., Joshi, H., Ram, K., Singh, N., Naja, M., Tiwari, S. (2017). Chemical characterization of rainwater at a high-altitude site "Nainital" in the central Himalayas, India. Environmental Science and Pollution Research, 24(4): 3959-3969. https://doi.org/10.1007/s1 1356-016-8093-z

[15] Yatkin, S., Adali, M., Bayram, A. (2016). A study on the precipitation in Izmir, Turkey: Chemical composition and source apportionment by receptor models. Journal of Atmospheric Chemistry, 73(3): 241-259. https://doi.org/10.1007/s10874-015-9325-1

[16] Akpan, A.O., Udosen, E.D., Offiong, N.A.O. (2018). Rainwater chemistry within the vicinity of Qua Iboe estuary, Nigeria. CLEAN-Soil, Air, Water, 46(3): 1700114. https://doi.org/10.1002/clen.201700114

[17] Nadzir, M.S.M., Lin, C.Y., Khan, M.F., Latif, M.T., Dominick, D., Hamid, H.H.A., Lazim, M.A.S.M. (2017). Characterization of rainwater chemical composition after a Southeast Asia haze event: Insight of transboundary pollutant transport during the northeast monsoon. Environmental Science and Pollution Research, 24(18): 15278-15290. https://doi.org/10.1007/s11356-017-91311

[18] Friedler, E., Gilboa, Y., Muklada, H. (2017). Quality of Roof-harvested rainwater as a function of environmental and air pollution factors in a coastal Mediterranean city (Haifa, Israel). Water, 9(11): 896. https://doi.org/10.3390/w9110896

[19] Qin, H.P., Tang, Q.L., Wang, L.Y., Fu, G. (2015). The impact of atmospheric wet deposition on roof runoff quality in an urbanized area. Hydrology Research, 46(6): 880-892. https://doi.org/10.2166/nh.2015.209

[20] Nalwanga, R., Muyanja, C.K., McGuigan, K.G., Quilty, 
B. (2018). A study of the bacteriological quality of roofharvested rainwater and an evaluation of SODIS as a suitable treatment technology in rural Sub-Saharan Africa. Journal of Environmental Chemical Engineering, 6(3): 3648-3655. https://doi.org/10.1016/j.jece.2016.12.008

[21] Charters, F.J., Cochrane, T.A., O'Sullivan, A.D. (2016). Untreated runoff quality from roof and road surfaces in a low intensity rainfall climate. Science of the Total Environment, 550: 265-272. https://doi.org/10.1016/j.scitotenv.2016.01.093

[22] Carlton, J.S. (2013). Water quality of roof-harvested rainwater in central Texas (Doctoral dissertation, Stephen F. Austin State University). Dissertations \& Theses - Gradworks, 2013.

[23] Gu, M.Z., Chang, S.Y., Xu, W., Zhan, Q. (2018). Classification of rainwater runoff pollution indexes and analysis of pollution sources in Tianjin urban area. South-to-North Water Transfers and Water Science \& Technology, $16(5)$ : https://doi.org/10.13476/j.cnki.nsbdqk.2018.0128

[24] Zhou, B., Zhang, Q.Q., Miao, L.P., Geng, Y.D. (2016). Study on rainfall runoff characteristics of asphalt roofing with different service years. Environmental Science and Technology, 2016(S1): 236-242. https://doi.org/10.3969/j.issn.1003-6504.2016.S1.046
[25] Che, W., Wang, H.Z., Ren, C., Liu, H., Meng, G.H. (2001). Studies on roof runoff pollution and utilization in Beijing urban urea. China Water \& Wastewater, 17(6): 57-61. https://doi.org/10.3321/j.issn:10004602.2001.06.019

[26] Zhang, K.F., Sui, T., Chen, S.F. (2008). Analysis of water quality characteristics of rainwater in Jinan City. Journal of Irrigation and Drainage, 2008(05): 119-121. https://doi.org/10.13522/j.cnki.ggps.2008.05.005

[27] Yantai Government portal of China. Overview of Yantai [EB/OL].(2017-03-01)[2018-01-05]. http://www.yantai.gov.cn/col/co153/index.html.

[28] Meera, V., Ahammed, M.M. (2018). Factors affecting the quality of roof-harvested rainwater. In Urban Ecology, Water Quality and Climate Change, 84: 195202. https://doi.org/10.1007/978-3-319-74494-0_15

[29] Lee, J.Y., Bak, G., Han, M. (2012). Quality of roofharvested rainwater-comparison of different roofing materials. Environmental Pollution, 162: 422-429. https://doi.org/10.1016/j.envpol.2011.12.005

[30] Liu, D.X., Li, Q.Q., Li, T.L., Wang, W., Jin, C.H. (2016). Study on characteristics of roof runoff water quality in the northern coastal city and its influencing factors. Environmental Science \& Technology, 39(12): 100-105. https://doi.org/10.3969/j.issn.1003-6504.2016.12.017 